\section{A saúde pública em tempos de burocratização: 0 caso do médico Noel Nutels}

\section{Public bealth in times \\ of bureaucratization: the case of the physician Noel Nutels}

Carlos Henrique Assunção Paiva

Mestre em saúde coletiva pelo Instituto de Medicina Social da Universidade do Estado do Rio de Janeiro (IMS/UERJ).

Rua Paratinga, 700

21230-770 Rio de Janeiro - RJ Brasil mors@ig.com.br
PAIVA, C. H. A.: 'A saúde pública em tempos de burocratização: o caso do médico Noel Nutels'. História, Ciências, Saúde - Manguinhos, vol. 10(3): 827-51, set.-dez. 2003.

Este artigo discute a trajetória do médico sanitarista Noel Nutels como um estudo de caso. Meu argumento central é que a história da saúde pública, a partir dos anos 1930, sobretudo durante o longo período getulista, é marcada por um processo de burocratização, cujo principal resultado é uma crescente dificuldade na implementação das políticas públicas durante o período. Esta dificuldade indica um gradual conflito nas relações entre aqueles diretamente responsáveis pela elaboração e implementação das políticas públicas e a crescente burocracia estatal.

O período histórico que se constitui a partir de 1930 assinala uma ampla divergência entre os padrões de comportamento dos 'homens de ciência' e dos 'homens de Estado'. Se o período anterior à revolução tem como marca uma certa sintonia entre esses dois segmentos sociais, a burocratização altera rápida e gradualmente o antigo equilibrio, conquistado ainda no final do século XIX, e promove um deslocamento do papel de destaque que até então desfrutavam os agentes e autoridades da saúde pública no interior dos aparelhos do Estado.

PALAVRAS-CHAVE: história do Brasil, história da saúde pública, Noel Nutels.

PAIVA, C. H. A.: 'Public health in times of bureaucratization: the case of the physician Noel Nutels'.

História, Ciências, Saúde-Manguinhos, vol. 10(3): 827-51, Sept.-Dec. 2003.

This case study of the trajectory of sanitarian Noel Nutels argues that starting in the 1930s and particularly during the long Vargas period, the history of Brazilian public health became characterized by a process of bureaucratization. Although the chief consequence was an increase in problems in implementing public policies, these difficulties do not appear to have prompted any immediate ideological demobilization within the sanitation movement, as occurred under the Old Republic, having instead engendered conflicts between those directly responsible for designing and implementing public policies, on the one hand, and the growing State bureaucracy, on the other. The historical period initiated in 1930 thus marked a broad divergence between the conduct of 'men of science' and 'men of State'. If the period preceding the revolution was characterized by a certain harmony between these two social sectors, won in the late nineteenth century, the process of bureaucratization altered this balance, dislodging public health agents and authorities from the special roles they had enjoyed within the Brazilian State machinery.

KEYWORDS: history of Brazil, history of public bealth, Noel Nutels. 
"Um dia (Noel Nutels) me disse que odiava 'a camisa-de-força da cidade grande'; e tinha verdadeiro horror às limitações kafkianas da burocracia, implacável monstro que tanto dificultou seu trabalho de médico e de apóstolo junto aos índios brasileiros" (depoimento de Joel Silveira, apud Houaiss, 1974, p. 68).

\section{Introdução}

- ste artigo é um segmento de uma pesquisa que se encontra em C andamento ${ }^{1}$. Sua proposta geral é compreender o impacto da burocratização, tanto da sociedade como do Estado, sobre a gerência da saúde pública a partir da década de 1930 até a de 1960. Nesse artigo, contudo, pretendo discutir alguns fatos acerca da trajetória do sertanista e médico tisiologista Noel Nutels, a fim de demonstrar empiricamente a hipótese de trabalho que venho colocando à prova no quadro geral de minha pesquisa. Quero propor, como hipótese de investigação, que a atividade do médico à frente de instituições como a Fundação Brasil Central (FBC) ou o Serviço de Unidades Sanitárias Aéreas (SUSA) está intimamente relacionada com a ideologia de salvação e construção nacional pela saúde pública proveniente do movimento sanitário da Primeira República (1889-1930). Em certo sentido, posso dizer que Noel Nutels estava mais inspirado no passado do que nos mecanismos burocráticos de ação do Estado que se pretendia instituir após a Revolução de 1930.

Quando comecei a estudar a trajetória de Nutels e o legado que o médico deixou nos inúmeros serviços que prestou a nossa sociedade, imaginava ver um homem realizado, que encontrou nas instituições do Estado pós-1930 - período em que ele atuou — toda uma gama de possibilidades técnicas e burocráticas que facilitaram sobremaneira suas incursões na saúde pública. Em certo sentido, deu-se o oposto. Ao examinar essa trajetória, pude observar que não foi o processo de centralização política e burocratização das instituições do Estado, gestado nos anos 1920 e, sobretudo, implementado a partir de Getúlio Vargas, que serviu o médico de facilidades e ferramentas para a realização de seus serviços. Aliás, facilidade não é o que ele parece ter encontrado no caminhar de sua vida profissional. O que ocorreu foi que o médico tinha um ideal, uma motivação que o fez se movimentar por inúmeras redes sociais e políticas da época e possibilitou que, bem ou mal, ele legasse toda uma obra à saúde pública. A história que conto é a história de como esse ideal se operou no dia-a-dia desse personagem.

Decerto que o Nutels profissional não está dissociado do ser humano que foi, dos laços e relações sociais que estabeleceu, dos encontros e desencontros com o seu tempo. Por isso, de um ponto de vista mais amplo, o exame de sua atuação profissional não pode fugir à tarefa de observar também sua vida na teia das relações sociais. Estas relações, 
vale dizer, mantinham ligações estreitas com os padrões de comportamento do indivíduo, com toda sua complexidade, sobretudo na esfera de atuação profissional que marcou o campo da saúde pública daqueles tempos.

É importante destacar desde já que qualquer pesquisa que aborde o trabalho ou a biografia de Noel Nutels seguramente, e com alguma razão, mostrará o repúdio do médico à retórica intelectual de pensadores que, segundo ele, nada faziam para transformar a realidade social de seu tempo. Nutels era um 'homem de ação'. Ao observar esse homem de ação, avesso à estagnação da teoria, o investigador, no entanto, corre muitas vezes o risco de cair nas ciladas da retórica do discurso do sertanista. Não é conveniente, a meu ver, conceber que as práticas sociais possam ocorrer de acordo com a idéia de espontaneidade. Sua espontaneidade, muitas vezes mencionada por seus biógrafos e amigos, não merece ser confundida com uma simples voluntariedade individual, pois se trata, antes, de uma espécie de interseção entre o indivíduo e a sociedade. É, em um sentido mais geral, uma manifestação social e histórica.

Quando Nutels criticava o trabalho e o envolvimento dos intelectuais de sua geração, devemos ter em mente que seus comentários não eram dirigidos a qualquer forma de pensamento que organizasse intelectualmente propostas e pretensões políticas, não era o seu alvo a atividade intelectual do ponto de vista genérico, mas uma forma particular de se conceber o intelectual, sobretudo, àquela vinculada à tradição dos bacharéis, típica da República Velha. O voto do jovem médico era a favor da inovação, queria despir-se do ranço parasitário das antigas oligarquias para se vincular a uma nova tradição, mais moderna, ligada à construção, pelas idéias, propostas e sua aplicação, à invenção de um país. Ao agir dessa maneira, paradoxalmente, ele mantinha os laços de continuidade com os sanitaristas do período anterior, sua arena de ação e discussão não parecia passar preponderantemente pela esfera técnico-burocrática, mas pela dinâmica e força da ideologia de salvação nacional da saúde pública, responsável pelo movimento sanitário dos anos 1920.

Em poucas palavras, a hipótese desse artigo é que o Estado após 1930 inaugura uma gestão burocrática, mas não um homem burocrático. Há laços de continuidades históricos que merecem ser examinados cuidadosamente, a fim de compreendermos os desafios dos novos tempos. Este texto, nesse sentido, pretende apenas chamar a atenção para esta possibilidade de análise.

\section{A trajetória}

\section{Os primeiros laços}

Os historiadores dizem quase em uníssono que foram tempos difíceis esses do nosso século XX. Não creio que possamos muito 
facilmente refutar essa imagem extremamente negativa do século passado. De forma dramática e muito cedo, Noel Nutels pôde conhecer a perversidade de algumas ideologias dominantes naqueles tempos em seu país de origem. Fugitivo da violência sustentada pelos pogrons russos, o jovem Nutels chegou ao litoral brasileiro com apenas oito anos de idade, na cidade de Recife dos anos 1920.

Assim, foi instalado nos trópicos que Nutels conheceria não só seu pai, que havia partido para a América do Sul em 1912, mas também a nova terra que ele assumiria, por força dos acontecimentos, como sua. Aqui ele trocou o russo e o iídiche pelo português, a neve e o frio quase polar pelo calor sem pausas e, finalmente, o medo da perseguição milenar por uma certa visão idílica de nosso país. Em depoimento, o médico disse que "na verdade, antes de iniciarmos a longa viagem, eu sabia apenas que o nosso destino era um paraíso situado numa região remota cujo nome, Zudamérica, significava para mim avesso de pogrom, fome e pobreza" (apud Houaiss, 1974, p. 13).

Na pequena cidade alagoana de Laje do Canhoto, segundo Orígenes Lessa (1978, p. 37), "nunca a nenhum lhe ocorreu chamá-lo de judeu", o que sinalizava, segundo o autor, para a tranqüila vida no agreste nordestino. Para Lessa, a condição de judeu era lembrada somente pelo padre francês que administrava a paróquia da cidade. Nas missas e pregações do celibatário europeu era comum ouvir-se comentários desfavoráveis aos judeus. Fato que não parece ter provocado qualquer constrangimento para a família que se fixara no município na década de 1920. A migração dos Nutels nos anos 1930 para a cidade de Recife deveu-se, sobretudo, à necessidade de continuação dos estudos do jovem Nutels.

Na ocasião, Salomão Nutels transferiu seus negócios da pequena Loja da Moda, na cidade de Laje do Canhoto, para uma fachada ao lado do Diário de Pernambuco. Ao contrário da estabilidade que o empreendimento usufruía no interior, ali ele encontrou um período de escassez fatal para a sua sobrevivência. Diante do sufoco provocado pela diminuição das vendas, a família Nutels resolveu então fazer de sua residência em Recife uma modesta, mas muito bem freqüentada, pensão. Creio que ali o jovem Nutels faria e consolidaria amizades providenciais para o seu futuro profissional.

Pela pensão da rua Gervásio Pires, 234, passaram freqüentadores ilustres. A começar por Rubem Braga. Braga foi para Recife enviado pelos Diários Associados de Assis Chateaubriand. O período como empregado nos Associados não foi longo, pois logo o jornalista se afastou e fundou um pequeno jornal chamado Folha do Povo. Na pensão dos Nutels, além de Braga, estiveram também o compositor Lourenço da Fonseca Barbosa, funcionário do Banco do Brasil conhecido pelo apelido de Capiba, assim como Saulo, João e Lucas Suassuna. 
Juntamente com o primeiro Suassuna, Nutels se formaria em medicina em Recife no ano de 1936.

\section{O médico Noel Nutels}

Sua primeira viagem ao Rio de Janeiro data de fevereiro de 1935, não como médico, pois não havia concluído o curso, mas como integrante da Jazz Band Acadêmica de Pernambuco. Os animados músicos vieram a convite do pernambucano, então prefeito, Pedro Ernesto. A Jazz Band, ao contrário do que o nome indica, era uma autêntica banda nordestina de forró e maracatu e suas apresentações no Rio foram, segundo a imprensa, de grande sucesso, graças às suas exibições para um grande público no Alhambra, cineteatro que deu lugar ao Hotel Serrador. A migração de Nutels para a capital da República só ocorreria dois anos depois, justamente quando ele foi procurar emprego e melhores condições de trabalho na capital federal.

Seu desempenho como estudante de medicina parece não ter sido dos mais brilhantes. Segundo depoimentos, Nutels não nutria muito interesse pelas disciplinas médicas (Houaiss, 1974, pp. 4457). Sua presença se justificava no curso mais em razão da pressão familiar, que via com bons olhos a possibilidade de ter um médico na família. A condição da família no passado ajuda-nos a atender um pouco melhor as iniciativas do jovem Nutels nos trópicos.

No contexto da época, em sua terra de origem era bastante inviável a um judeu freqüentar uma universidade e romper, desse modo, as fronteiras impostas pelo gueto. Um diploma de médico, em particular, sempre era visto como garantia de prestígio e segurança social, exatamente como no nosso país. Oferecer ao pai o diploma no final do ano de 1936, nos últimos dias de vida de Salomão Nutels, foi, segundo ele, uma questão de honra perante o pai enfermo.

Seu fraco desempenho como estudante de medicina não parece guardar relação com o médico competente das décadas posteriores. Suas atividades como médico sanitarista não devem ser confundidas como uma simples fuga da clínica. O que ele recusa é o tratamento individualizado, não a perspectiva que associa condições sociais e sintomas biológicos. Há alguns impressionantes depoimentos da época que demonstram a capacidade que o médico tinha em relacionar sintomas difusos a patologias. O estudante desinteressado, nesse sentido, parece ter se transformado, no mínimo, em um médico competente e respeitado por seus colegas.

Assim Noel Nutels retornou à capital federal, em 1937, por conta da promessa de conseguir o sonhado emprego como funcionário público. José Borba, seu amigo, alto funcionário do Ministério do Trabalho, havia sinalizado a possibilidade de Nutels servir como médico em alguma instituição do governo. No ato da nomeação, no 
entanto, era imprescindível que o nomeado fosse, ao menos, brasileiro naturalizado. Diante das exigências burocráticas que só foram definitivamente resolvidas em maio de 1938, com um decreto assinado por Getúlio Vargas, o aspirante a funcionário público perdera a vaga prometida sob a acusação de não ser um cidadão brasileiro.

O fato, inevitavelmente, provocou revolta e estranhamento ao médico que firmara sua identidade não só como brasileiro, mas sobretudo como nordestino, em razão de sua cultura e do seu fenótipo já por ele considerado nacionalizado pelas doenças que assolavam a gente do país. Segundo depoimento do médico:

Não sou mais judeu russo da Ucrânia, filho de judeus russos da Ucrânia. Sou é mulato sarará e dos bons. Cabeça chata, cabra safado. E aqui estou, brasileirinho da silva, nordestino de papo amarelo — documento da força da absorção desta terra selvagem. Com meu canudo de doutor, minhas marcazinhas de sífilis, aspirante a um emprego público, falando (mal) do governo (apud Lessa, 1978, p. 61).

Assim que chegou ao Rio de Janeiro, Nutels ligou-se imediatamente a um grupo de intelectuais constituído por indivíduos vindos de toda parte do país. Creio que essas ligações foram fundamentais para a trajetória profissional do médico, pois serviram como uma espécie de extensão dos laços sociais anteriores, estabelecidos ainda no Nordeste, e aqui reforçados, como também foram responsáveis pela criação de novos e importantes amigos, estes já instalados na capital da República. Samuel Wainer, Octávio Malta, Rubem Braga, Di Cavalcanti, Astrogildo Pereira, Osório Borba, entre outros, foram os responsáveis em abril de 1938 pelas primeiras páginas do periódico semanal Diretrizes. Diretrizes pode ser visto não só como um elo que uniu, pelas idéias e ideais, intelectuais tão atuantes na história política e social do país, mas também como uma espécie de fórum de discussões que privilegiava os dilemas e mazelas que estigmatizavam o nosso país.

Em depoimento em abril de 1973, Otávio Malta fala sobre a relação de Nutels junto ao grupo de Diretrizes: "Noel Nutels tinha sua base dialética. Sua origem hebraica conduzia-o aos objetivos políticos de nosso grupo: combater informando, analisando, debatendo, rindo, o problema nazi-fascista, juntamente com os da nação" (Houaiss, 1974, p. 72).

Não há informações precisas acerca da entrada de Nutels no grupo que fundaria o periódico Diretrizes. Otávio Malta (idem, ibidem, p. 71) mencionou que não sabia "como Noel Nutels chegou a se ligar ao grupo de Diretrizes". Para Lessa (1978, p. 62), "ligações anteriores (de Nutels) com pernambucanos, baianos, judeus, gente de Sergipe e de Alagoas o aproximaram do grupo de Diretrizes". É provável ainda que seu antigo amigo da velha pensão dos Nutels, Rubem Braga, o tenha introduzido nessa ala da intelligentsia brasileira. De qualquer forma, 
não resta dúvida de que a instalação do jovem na capital federal se deu sob a segurança dos laços de amizade estabelecidos anteriormente, ainda no Nordeste.

O fato é que a ligação com esse grupo por si só traz um dado ideológico interessante. Os membros de Diretrizes, apesar da diversidade dos personagens, eram reconhecidamente militantes comunistas, desde os de "carteirinha", filiados ao partido, como Jorge Amado e outros, até os simples "simpatizantes", como Samuel Wainer e o próprio Nutels. A rigor, todos comungavam de uma mesma visão bastante politizada da sociedade brasileira, que encarava a população desse país, ou um segmento desta, como motor das transformações sociais tão desejadas, o que, por sinal, matizava a prática de inúmeros militantes de esquerda naqueles tempos.

À medida que o periódico foi imprimindo os seus primeiros passos na história da imprensa brasileira, o grupo arregimentava novos colaboradores. A partir do segundo número, participam Jorge Amado, Graciliano Ramos, José Lins do Rego, Rachel de Queiroz e Aníbal Machado. O círculo de relações pessoais de Nutels parece ter se alargado imensamente nos últimos anos da década de 1930, ainda na capital federal, e as reuniões em torno do periódico Diretrizes parecem ter colaborado para isso.

Nesse momento, após ser naturalizado brasileiro, surgiu a possibilidade de Nutels trabalhar finalmente como médico. Com a ajuda de José Borba e outros amigos de Diretrizes, o jovem médico vinculou-se aos quadros do Instituto Experimental Agrícola, em Botucatu (SP). A passagem de Nutels por São Paulo fora rápida; Elisa, sua esposa, optou na ocasião por não sair do Rio, onde trabalhava em um escritório e recebia um salário algumas vezes maior que o do marido. Não é difícil compreender por que Nutels foi com o objetivo de retorno breve.

Em 1940, mais uma vez por conta da ajuda dos amigos de Diretrizes, Nutels passou ao combate da malária no km 47 da estrada Rio — São Paulo, em terreno onde seriam construídas as futuras instalações da Universidade Federal Rural do Rio de Janeiro (UFRRJ). A transferência ocorrera para que o jovem médico trabalhasse nas obras de saneamento da Baixada Fluminense, vinculadas ao Ministério da Agricultura. Nesse período, ele instalou-se em um pequeno posto de saúde em uma das regiões mais infestadas pela malária do estado do Rio de Janeiro. Nutels estava, contudo, mais próximo dos amigos, muitos dos quais ainda ligados ao periódico Diretrizes, cuja sede informal era exatamente o Amarelinho da Cinelândia, restaurante situado no centro do Rio.

No início da década de 1940, novos colaboradores ingressaram no periódico carioca, entre eles, Afonso Arinos de Melo Franco, Austregésilo de Athayde, Cassiano Ricardo, Edison Carneiro, Érico Veríssimo, Manuel Bandeira, Gilberto Freyre. O empreendimento se solidificava na arena política da imprensa brasileira, mas não estava livre de novas contradições e conflitos. Diretrizes instituiu concursos e prêmios para trabalhos escritos 
por leitores, como o concurso para a Pequena História da República para Crianças, em 1940. Os laços com o Departamento de Imprensa e Propaganda (DIP) se fortaleciam com a participação nas comissões julgadoras de Lourival Fontes. Era nítida a intenção dos editores de se aproximarem do Estado através da figura de seu censor (Weiner, 1989).

Nesse momento, Nutels começou a sua experiência de vida rumo ao interior do país, afastando-se por longos períodos das discussões políticas nacionais que seus amigos levantavam na imprensa. A partir da década de 1940, o intelectual começou sua longa carreira de desbravador dos sertões brasileiros. São os primeiros tempos do médico sertanista.

\section{Nutels na Expedição Roncador-Xingu}

A Expedição Roncador-Xingu foi organizada em 6 de junho de 1943, por iniciativa da Coordenação da Mobilização Econômica, órgão criado em setembro de 1942 que funcionava, naquele contexto, como um superministério. Ele tinha funções bastante amplas, desde fixação de preços até planejamento dos meios de transporte. No clima político motivado pelo conflito mundial, a expedição teria como função primordial mapear as riquezas naturais e promover a colonização do interior do país (Menezes, 2000, pp. 29-51) e atuou no cenário nacional até 1967, quando foi finalmente incorporada à Superintendência de Desenvolvimento do Centro-Oeste (SUDECO).

A criação da expedição, segundo Mariza Paz (1994), deve ser compreendida num quadro internacional mais amplo. Para a autora, $\mathrm{O}$ governo Vargas decidiu investir na marcha para oeste por razões políticas e econômicas. Paz lembra a sugestão do barão Shudo, representante japonês na Liga das Nações Unidas no ano de 1937, que propôs, naquela ocasião, que áreas consideradas desocupadas no planeta deveriam ser exploradas para o bem comum de todos os povos, o que parecia, para muitos, um ataque à soberania do Brasil. Um pouco mais adiante, em 1942, o ministro francês Paul Reynaud propôs a utilização dos "espaços vazios" do interior do nosso país para a criação do então almejado "espaço vital" para os agitados alemães do período entreguerras. ${ }^{2}$

A autora lembra também a conjuntura que se iniciou em meados de 1942, com os ataques alemães a navios de bandeira nacional no litoral brasileiro, o que agravaria o clima, segundo ela, de ameaça de uma ocupação alemã no nosso país. Clima de ameaça reforçado também, é claro, pela presença e pressão norte-americana com a chegada de tropas no Nordeste brasileiro desde o final de 1941. Essa conjuntura, segundo os historiadores, parece ter dado um novo rumo na definição do governo Vargas na política externa (Fausto, 2000, pp. 380-4). 
Frente a esse contexto internacional bastante amplo, a criação da Fundação Brasil Central (FBC) e a seqüência de expedições que esta patrocinou, teriam como intenções ocupar e defender o país; promover a interiorização da capital; desenvolver rotas e acessos ao interior e, finalmente, criar nova estrutura agrária que incrementasse a economia brasileira.

O contexto internacional não pode ser desprezado a pretexto de que a história do Brasil possa ser compreendida somente em razão de suas forças ou realidades internas peculiares. No entanto, é preciso aliarmos a história desse país à conjuntura internacional daqueles tempos, a fim de evitarmos os riscos de interpretarmos à realidade nacional como uma conseqüência mecânica dos acontecimentos estrangeiros. Além disso, é bom lembrarmos, como exemplo, que as caminhadas de Belisário Penna e Arthur Neiva (1912) pelo norte da Bahia, sudoeste de Pernambuco, sul do Piauí e por todo Goiás não tiveram relação direta com os eventos da história política ou econômica internacional. Foi, nesse sentido, um movimento genuinamente nacional.

Assim creio que podemos considerar as investidas rumo ao interior do país como vertentes de um processo que se inicia certamente antes do conturbado período de 1930. Os trabalhos de Castro Santos (1993, 1987, 1985, 1980), Hochman (1998) e Lima (1999) já foram suficientemente convincentes ao demonstrar que é no contexto da Primeira República que surgem condições nacionais próprias que favoreceram os investimentos do movimento sanitário. E nesse contexto o interior do país era um alvo privilegiado dos movimentos políticos e dos médicos sanitaristas.

Nísia Trindade Lima (1999, p. 65) particularmente demonstrou como as visões sobre o sertão e os sertanejos têm-se polarizado, desde fins do século XIX, entre uma perspectiva que considerava o interior como espaço de barbárie, e outra, mais moderna, que o idealizava como o locus da autêntica identidade nacional. Personagens como Euclides da Cunha, Roquette-Pinto, Belisário Penna e Monteiro Lobato podem ser encarados como representantes de uma corrente que visava a incorporação do sertão, corrente cujas propostas deram corpo e alma aos projetos de saneamento e educação dos habitantes da hinterlândia brasileira. Nas palavras da autora: "Os primeiros anos da República foram palco de um expressivo movimento de valorização do sertão, seja enquanto espaço a ser incorporado ao esforço civilizatório das elites políticas do país, seja como preferência da autenticidade nacional."

Com isso, é importante que de imediato possamos considerar as ações promovidas pela FBC não só como respostas a uma conjuntura internacional hostil, mas também como elementos dentro de um certo sentido de continuidade histórica que as forças políticas e sociais do Estado técnico-burocrático não conseguiram solapar integralmente. Ao 
contrário, em virtude dos acontecimentos mundiais, Vargas acabou por alimentar politicamente o que se operava no seio do pensamento social há muito tempo.

Por isso é danoso ao entendimento desse período, no que se refere às políticas públicas, considerarmos apenas a dimensão dos atos e fatos políticos e institucionais. Decerto não foi por acaso que em setembro de 1943, exatamente três meses após a criação da Expedição Roncador-Xingu, ela tenha sido considerada pelo decreto 5.801, de 8.9.1943 como uma instituição de interesse militar. Quero dizer que o processo de interiorização pode ser compreendido, do ponto de vista dos seus executores, como aquém dessa fronteira conjuntural marcada pelos acontecimentos políticos, pois se examinarmos a história da saúde pública do período exatamente anterior, como fez a literatura já mencionada, passaremos a interpretar corretamente o sentido de continuidade que todo esse investimento trazia consigo. Ocorre que, do ponto de vista do Estado, gradual mas progressivamente, a manutenção das políticas sociais torna-se tarefa não prioritária. No entanto, no plano da ação dos sanitaristas, não percebemos exatamente uma ruptura nos mesmos termos que a operada no seio de Estado.

Castro Santos $(1987 ; 1985)$ sugere que o esvaziamento do movimento sanitário se deu justamente graças à manobra de Vargas de impulsionar os sanitaristas, como Nutels, para regiões de vazio demográfico. Sendo assim, na fronteira os doutores estavam longe da possibilidade de criar problemas políticos para as velhas oligarquias do sertão. $\mathrm{O}$ autor interpreta a manobra como uma estratégia de não enfrentamento político, o que de alguma forma reforça o sentido de continuidade histórica que venho sugerindo, pois, nesse caso, a manobra de Vargas seria menos a "criação" de uma ideologia de salvação nacional pelo sertão, e mais uma mudança de alvo do que já se operava antes. Sem mudar sensivelmente o tom dos sanitaristas de então, Vargas emprestou-lhes uma nova direção, geopoliticamente definida por exclusão à oligarquia nordestina. Desse modo, não é em Vargas que devemos buscar a politização que move a saúde pública e os atores sociais, como Noel Nutels, mas antes da Revolução de 1930.

No entanto, quero esclarecer que o que pretendo examinar com a construção da trajetória de Nutels não é um mero continuum do movimento sanitário, cujas raízes estão na Primeira República, mas sobretudo compreender uma certa justaposição da mentalidade ou da ideologia que deu forma ao movimento sanitário com uma nova maneira de se operar no campo político, característica dos períodos subseqüentes a 1930, que denomino técnico-burocrático. Médicos como Nutels não são meros sobreviventes, heranças de um período que já passou, pois ele não parece ser uma personagem completamente estranha ao seu tempo. Ocorre que em sua época 
começam a surgir dificuldades de ordem política e social que não foram favoráveis à atuação de indivíduos com determinado padrão de comportamento estranho à ordem burocrática que se pretendia instituir. $^{3}$

Sabemos que o trabalho de Nutels com as populações indígenas começou justamente a partir de 1943, quando ele decidiu participar da Expedição Roncador-Xingu (Costa, 1987). A expedição que foi organizada no governo de Getúlio Vargas, exatamente no período da Segunda Guerra Mundial, tinha como grande objetivo, como vimos, desbravar os vazios demográficos no interior do país. Cabia 'burocraticamente' aos membros da expedição, num primeiro momento, criar campos de pousos aéreos, a fim de permitir a construção de uma rota aérea que ligasse o sul ao norte pelo interior do continente, promovendo assim o reconhecimento das áreas do interior do país junto ao recém-fundado Ministério da Aeronáutica (decreto 2.961, de 20.1.1941).

A expedição estava ligada administrativamente à $\mathrm{FBC}$ e era chefiada por João Alberto Lins de Barros, então ministro da Coordenação Econômica, de quem partiu o convite para que Nutels trabalhasse no interior do país. Certamente os conhecimentos e a experiência de Nutels com a malária na Baixada Fluminense foram fundamentais para sua indicação para os quadros da fundação.

Assim descreve Noel Nutels a rotina de seus primeiros trabalhos frente à FBC: "A nossa primeira tarefa, em todo lugar que chegávamos, era fazer campo de aviação. Eu ia num teco-teco, descíamos na selva e eu medicava o pessoal doente. Foi aí que tive os primeiros contatos com o problema do índio, foi em 1946" (O Pasquim, 28.4-3.5.1970, apud Houaiss, 1974, p. 23).

João Alberto, conhecido tenente das reviravoltas e revoluções da década de 1920 até a emblemática Revolução de 1930, conhecia bem o vida dos jeca-tatus do interior do país. Entre 1925 e 1927 ele foi, juntamente com Luís Carlos Prestes e a Coluna Miguel CostaPrestes, um dos andarilhos que verificou as condições de vida e miséria das populações do interior do Brasil. Por isso a FBC pode ser vista também como uma intenção que vinha de longa data nos planos do ministro, seu objetivo era intervir num quadro social que não sofrera mudanças radicais se comparado às décadas anteriores. Naquele contexto, não era propriamente o indígena que interessava a João Alberto e sua equipe, mas o homem comum, um sertanejo qualquer, indígena ou não.

O trabalho de Nutels e das instituições vinculadas ao saneamento no interior do país, em certo sentido, confirmou os argumentos anteriores sobre as condições de vida dos brasileiros, frutos das viagens que já mencionei de Belisário Penna e Arthur Neiva pelo Brasil. Para estes, o sertanejo, o habitante do interior do território brasileiro vivia sob o abandono e desamparo das autoridades públicas, sob condições 
sanitárias consideradas inadequadas, que, por sua vez, eram responsáveis pelo elevado número de vítimas de doenças facilmente controláveis.

A carreira de Nutels como tisiologista começou com os trabalhos da expedição, que, se não fossem as atuações dos médicos e dos irmãos Villas-Boas, estaria restrita à execução dos serviços militares e estratégicos impostos pelo governo. No entanto, em 1947, ele participou do que seria a primeira vacinação em massa de BCG do planeta em campos distantes das fronteiras da civilização. Em 1949, logo após a nomeação dos Villas-Boas como chefes da expedição Roncador-Xingu em substituição ao tenente-coronel Flaviano Matos Vanique, homem de confiança de Vargas, Nutels foi nomeado por João Alberto médico da expedição. Consolidava-se assim cada vez mais a formação do médico como sanitarista. Médico não só de um, outro ou alguns, tornava-se médico de multidões. Por isso Rachel de Queiroz disse que ele "nunca passou de médico sanitarista: o fato de exercer o sanitarismo entre os índios não alterava em nada a profissão" (Houaiss, 1974, p. 143).

A experiência é tão emblemática na carreira de Nutels que, não àtoa, em 1951, foi ao Rio de Janeiro freqüentar um curso de especialização para aprimoramento na luta contra a tuberculose. O médico já tinha o seu trabalho reconhecido nacionalmente, o que certamente facilitou sua entrada no Serviço Nacional de Tuberculose (SNT), que precisava urgentemente de reforço nos seus quadros. O curso de especialização, organizado pela instituição, convocava médicos de todo o país para oito meses de trabalho. Esse curto período de tempo, contudo, promoveu o nascimento da inovadora idéia de se constituir um serviço aéreo de atendimento médico às populações do interior do país. O desafio era conquistar novos adeptos de outros ministérios, especialmente do Ministério da Aeronáutica. No final do curso no Rio de Janeiro, Nutels foi nomeado médico dos quadros do SNT. Nascia o Nutels tisiologista.

No final do curso no SNT, Nutels dirigiu-se ao gabinete do então diretor do serviço, o professor Pereira Filho, a fim de pleitear o aparelho de raios $\mathrm{X}$, vital para a eficiência de seu trabalho no interior do país. Antes que Nutels esclarecesse o porquê da audiência, o diretor disse que ele já estava admitido, sem prejuízo para o seu contrato com o Ministério da Agricultura, a qual estava ligada a FBC. Não querendo fugir à finalidade de sua visita ao gabinete, Nutels fez a sugestão que ele mesmo considerou "negócio de judeu". Nas palavras do médico: "É simples. Eu the trago dois índios com pênfigo do melhor para os senhores estudarem com calma o problema e o senhor me arranja um raios $\mathrm{X}$ sem o qual nós não podemos trabalhar direito lá no mato..." (Lessa, 1978, p. 94). 
No mesmo período, juntamente com os Villas-Boas, Darcy Ribeiro, Heloísa Alberto Torres, José da Gama Malcher e Rondon, Nutels conseguiu uma audiência com o presidente Getúlio Vargas. A intenção do grupo era apresentar e sensibilizar o governo para a viabilidade do serviço de assistência médica aérea. O contexto político e social, no entanto, não era dos melhores. A conturbação política era intensa e estava - o futuro revelaria - prestes a ganhar novo sentido com os acontecimentos do dia 24 de agosto. Naquele contexto, infelizmente, o projeto não foi absorvido pelo Estado. Assim, durante o período de 1952 até 1956 a equipe organizada por Nutels atuou no campo da saúde pública, realizando abreugrafias e vacinações, de maneira extremamente improvisada, à margem do reconhecimento oficial do Estado, pois dependeu da obtenção de recursos e apoio, como, por exemplo, da aviação, graças às relações pessoais de seu criador e gestor (Costa,1987, 393). Somente em 1956, a idéia começou a se materializar para ser efetivamente realizada no governo seguinte. Era o prenúncio do Serviço de Unidades Aéreas (SUSA).

A causa da demora da instalação do SUSA é plural. Os anos 1950, quando foi gestada a idéia, foram um período política e economicamente conturbado. O presidente Dutra tinha enfrentado importante problema nas contas públicas, proveniente de um certo liberalismo às cegas. No entanto, ao final de seu governo, por conta de um enrijecimento do Estado nos assuntos públicos, o governo superou o quadro considerado grave e o país deu até sinais de crescimento econômico. O combate à crise econômica se fez acompanhar, por sua vez, pelas perseguições políticas que adentraram o governo de Getúlio Vargas, a partir de 1951.

O quadro de crise política e econômica, no entanto, não é suficiente para explicar o descaso do governo e da burocracia pública ao projeto de Nutels. Afinal, os anos 1920, período que marca o auge do movimento sanitário, não pode também ser considerado exatamente a bonança adequada para a execução de projetos públicos, sobretudo aqueles considerados, muitas vezes, não prioritários, como os "sociais", que hoje incluem a educação e a saúde.

O fato é que, no início do século XX, saúde não era um assunto "social", de acordo com o sentido que atualmente atribuímos a ela, isto é, como algo que constituiu uma arena relativamente autônoma das outras esferas da sociedade brasileira. Temos que ter em mente que a ação dos médicos estava visivelmente "contaminada" pelos assuntos políticos, econômicos e sociais propriamente ditos, pois a primazia da saúde e da higiene perante os demais significava que o tratamento dos males do corpo era condição sine qua non para o aniquilamento das outras mazelas de nossa sociedade.

Não posso considerar que em meados do século XX essa dimensão da saúde estivesse inalterada, sobretudo com relação ao sentido anteriormente mencionado. A existência de um ponto de vista mais 
técnico e burocrático e a significativa diversificação do corpo de funcionários, com o acesso de novos segmentos sociais não só para as principais cadeiras do Estado, mas também para os lugares mais subalternos, têm sintonia com uma mudança importante na concepção que orientou o funcionamento das instituições governamentais no âmbito da sociedade brasileira. ${ }^{4}$

Com as administrações posteriores a Getúlio Vargas, a estrutura e a organização do Estado e seu papel frente à economia tornaram-se questão recorrente no pensando social brasileiro. Com a precedência das condições político-administrativas e econômicas, com relação à saúde e ao saneamento, a atenção dispensada aos sanitaristas naturalmente diminuiu. Isto sem considerarmos a redução da participação destes em quadros de decisão administrativa para o setor.

Assim é tão-somente com Juscelino Kubitschek que o plano de desenvolver um sistema de atendimento médico (saneamento e higiene) aéreo finalmente saiu do papel para se tornar realidade, graças ao apoio fundamental do então ministro da Saúde, Maurício de Medeiros. Em depoimento ao Diário Carioca de 28 de agosto de 1956, o ministro disse que: "A idéia das Unidades Sanitárias Aéreas não foi minha. Resultou da conversa com um colega sertanista, o dr. Noel Nutels, que já trabalhou no Serviço de Proteção ao Índio e foi companheiro de João Alberto na corajosa aventura da Fundação Brasil Central."

A partir daí, Nutels se notabilizaria definitivamente não só como um dos maiores sertanistas do país, mas também como figura ilustre no rol da elite de médicos sanitaristas da medicina brasileira, tornando-se, inclusive, conhecido internacionalmente por conta do impacto no exterior de suas intervenções junto às comunidades indígenas que despertavam imensa curiosidade, sobretudo, nos europeus.

Se considerarmos que, do ponto de vista dos interesses do Estado, o contexto não era radicalmente outro, se comparado ao governo Dutra e à segunda gestão Vargas, qual foi o quadro que permitiu o início do projeto SUSA? Uma possibilidade de análise é vasculharmos a teia dos relacionamentos sociais que Nutels soube muito bem explorar em seu tempo.

\section{Os velhos e os novos tempos}

Há, sem dúvida, uma dimensão da personalidade de Nutels que é muito difícil de descrever e mais ainda de inferir alguma conclusão que aproxime fatos numa relação de causa e efeito. A maneira de agir ou de se comportar extremamente espontânea, que muitos de seus companheiros destacam em depoimentos, certamente tem a ver com a imagem de uma pessoa que tinha imensa capacidade e habilidade para se relacionar socialmente, de propor e de fazer entender, muitas vezes, pontos de vista alternativos ou não muito óbvios. 
Compreender a movimentação do médico no cenário político e social de seu tempo é também visualizar a forma como se relacionava socialmente: o universo da troca de favores, o patrimonialismo, as dádivas, as relações de pessoa a pessoa. Estou falando de um campo em que a movimentação não se dá por leis ou regras burocráticas, quaisquer que sejam, trata-se de uma arena regida pelo silêncio das normas sociais. Aqui não há apenas indivíduos, nem cidadãos politicamente organizados, mas pessoas que fazem das diferenças pessoais e sociais trampolim para as negociações, para a circulação de favores e de dívidas. Nesse campo não me resta dúvidas de que Nutels era um mestre.

O jornalista Pedro Dantas, de O Estado de S. Paulo de 25 de março de 1973, elaborou a pergunta que motiva essencialmente esse trabalho de pesquisa. O jornalista escreveu: "Como exprimir, então, o desapego do interesse material com que (Nutels) exercia a (medicina) e a quase preocupação em não aparentar, não deixar perceber sua condição profissional?" O próprio Dantas sugere uma resposta quando diz que Nutels ia além da medicina, quando se situava no campo da enfermagem, na esfera em que o cuidar e o amparar são mais importantes que a intenção de cura, quase sempre abrupta, que a medicina de então e dos dias de hoje procura instituir.

A pergunta que surge quando entramos em contato com trajetórias bem-sucedidas, como a de Noel Nutels, é, em outros termos, a seguinte: se o período inaugurado por Getúlio Vargas não estava inteiramente favorável à sustentação das velhas diretrizes do movimento sanitário, por conta do avanço avassalador da burocratização, ${ }^{5}$ como Nutels conseguiu bem ou mal viabilizar seus projetos? A chave parece estar também na própria figura de Nutels. Cabe aqui pensarmos o indivíduo como um sujeito interacional que mantém relações com múltiplas idéias, ideologias e grupos sociais. Embora o médico vivesse em um período em que as palavras de ordem eram a técnica e a eficiência, o plano das relações sociais não confirmava integralmente a rotina proposta pela burocracia varguista. Embora Nutels fizesse parte dos quadros do Estado, ele não comungava com os mesmos preceitos tecnicistas vigentes. Posso dizer que o seu grupo de referência, de acordo com a noção de Merton (1968, pp. 306-88), estava em um outro momento, aquém, de forma hegemônica, da realidade social do período pós-1930.

Assim o ponto de partida do nascimento do SUSA pode ser visto como um excelente exemplo da habilidade de Nutels em tecer amizades e consolidar projetos políticos. Acontece que o ministro de Juscelino Kubitschek, Maurício de Medeiros, era tio do jornalista Paulo de Medeiros e Albuquerque, amigo de Nutels pelas andanças entre as matas do interior do país. Foi Paulo quem apresentou as idéias de Nutels ao então ministro, que, médico de formação, mostrou-se entusiasmado. $\mathrm{O}$ problema era conseguir um serviço aéreo regular, despesa considerável 
para aqueles tempos. Conta Orígenes Lessa (1978) que foi numa conversa entre sobrinho e tio, que ambos se lembraram que o ministro da Aeronáutica era irmão, por parte de mãe, do próprio Maurício de Medeiros, o que facilitaria infinitamente o andamento não burocrático das coisas. Assim nasceu efetivamente o SUSA.

Decerto que havia algo político no contexto que viabilizou o que desenrolara nas relações sociais. Não quero jamais propor que a criação do SUSA foi possível tão-somente pela vontade de um indivíduo, por mais esforçado e determinado que este fosse. É bom lembrarmos que a preocupação com a ocupação efetiva do interior do país não é exatamente um fato novo. Como vimos, desde os primórdios do século XX havia muita discussão com relação ao destino do interior, desde então denominado sertão. Talvez, naquela ocasião, o dilema era menos com relação à hinterlãndia, como espaço geográfico físico definido, e mais com relação ao homem que vivia nessas regiões, consideradas insalubres e abandonadas. A diferença entre homem e espaço físico é importante porque até meados do século XX as motivações foram outras, que não as do contexto do pós-guerra. Nesse momento podemos observar uma série de motivações de ordem política e econômica com o fim de explorar as regiões abandonadas. Do ponto de vista do Estado, a qualidade de vida daqueles que viviam não parecia ser exatamente um problema primário, mas sim a utilização dos recursos minerais, hídricos e naturais, de um modo geral.

Assim se houve uma investida no sentido de melhoria efetiva das condições de saúde daquelas populações, no correr dos anos 1950, não podemos considerar o interesse das elites governamentais brasileiras como o ponto de partida de sua elaboração e execução. Pois parece estar no campo de ação de determinados indivíduos, cujo grupo de referência é outro que não o daqueles, a chave para compreendermos as potencialidades e os limites dos projetos de políticas públicas.

É bom lembrarmos, para ficarmos na gestão Juscelino, que o plano do presidente nem sequer previa algum investimento estrutural no setor da saúde. Ele estava inteiramente voltado para o crescimento econômico, com todo o investimento no processo de industrialização e a instalação de um mercado interno no país. A melhoria das condições de saúde, sabidamente aviltantes, como já comentei, seria daí decorrente. Surge assim uma espécie de reinado do discurso econômico sobre os demais, um economicismo que se estende até os nossos dias, e que provocou, infelizmente, ecos entre os próprios sanitaristas.

\section{Nutels e o Serviço de Unidades Sanitárias Aéreas}

O pessoal do SUSA iniciou suas atividades na segunda metade de 1956 e Nutels serviu como diretor da instituição desde a sua fundação até 1973, quando faleceu no Rio de Janeiro. No Correio da Manhã de 
23 de janeiro de 1957, o próprio Nutels avaliou de maneira muito positiva o resultado dos primeiros meses de funcionamento do serviço que dispunha de apenas de uma aeronave. A equipe, constituída por clínico-geral, dentista, oftalmologista, operador de raios X, laboratorista e auxiliares, prestou, segundo depoimento do médico, 33.474 atendimentos em apenas seis meses de funcionamento. Em exatos 104 dias de ação em 17 localidades das regiões Norte e Nordeste, o SUSA elaborou diversos cadastros torácicos, vacinações por BCG, antivaríola, antiamarílica e exames diversos de assistência dentária e oftalmológica.

Entrevistas do médico ao Jornal do Brasil e ao Correio da Manhã de janeiro de 1957 revelam um profissional que transborda otimismo com relação ao futuro do novo serviço médico. Não à-toa, a partir de 1957, Nutels conseguiu aumentar sua equipe, o que indicava um efetivo crescimento da capacidade de atendimento do serviço naquele ano.

O SUSA dispensava especial atenção ao combate da tuberculose. Para conquistar a adesão das populações rurais, o médico chegou a financiar a edição de um livreto de cordel intitulado A fera invisível ou o triste fim de uma trapezista que sofria do pulmão, escrito pelo pernambucano João José da Silva, que recebeu instruções do próprio Nutels sobre a natureza do mal que atacava sobretudo as populações mais pobres. Toda essa estratégia de contato com as populações do interior era completada com a agenda de shows de música que a equipe promovia a fim de atrair a atenção da comunidade alvo da saúde pública.

O objetivo era relativamente simples: colocar as populações que sofriam com o flagelo da tuberculose em contato com o esotérico conhecimento médico. Em linguagem popular e acessível, homens, mulheres e crianças do campo vislumbraram a possibilidade de compreender um pouco mais como se dava o contágio e o tratamento do mal-dos-peitos. Práticas como essas demonstram que Nutels era o tipo de profissional que não agia habitualmente via medidas impostas de "cima" em nome de uma certa autoridade científica ou governamental, mas procurava atingir por "dentro", utilizando-se das tradições e da cultura local como estratégia para o estabelecimento de contato entre os saberes erudito e popular, relação social vital para a debelação ou o controle das doenças não só do interior, pode-se dizer. Aqui, um grande instrumento foi a compreensão do processo de saneamento como também uma questão de educação sanitária.

O índio cor-de-rosa, no dizer de Otávio Malta, é pois um excelente exemplo de profissional que utilizava como estratégia de trabalho o drible criativo das condições consideradas desafiadoras. Não era a obrigação da lei que parecia motivá-lo. A execução de seu papel social, o de médico, não parecia ser dado pelo lugar que ocupava na hierarquia das instituições do Estado, mas em razão de uma idéia-força 
prévia ao mando da lei. Sua intenção era transformar uma realidade social encarada como aviltante, tal qual nos tempos dos grandes médicos da Primeira República, quando salvar o país passava, como vimos, pela saúde pública. Nas palavras de sua filha, Bertha Nutels:

papai era o idealismo em pessoa, cara. Ele tinha muito tesão pelo que ele fazia, não tem outra explicação não. Eu acho que nada é feito.... quer dizer, ter uma clínica ... não tinha nada a ver com o papai, nada a ver. Eu acho que sempre o que movimentou o papai, sempre tudo o que ele fez na vida, era através do ideal, era o ideal político, era o ideal patriota. Ele era um nacionalista, sem ser doente, não é? Um nacionalista saudável, porque o nosso Hitler também era nacionalista, né? (entrevista de Bertha Nutels a Carlos Henrique A. Paiva, jan. 2002).

Somente quando a força da ideologia esvazia-se no campo profissional médico é que encontramos com facilidade um tipo de profissional que executa suas tarefas, previstas por um código e restritas pela lei, de maneira burocrática e politicamente inofensiva à estrutura social que envolve tanto a doença como o doente. Esse tipo ideal, nos moldes weberianos, talvez muito representativo dos profissionais dos dias atuais, encarna muitas vezes suas atividades como uma simples prestação de serviço a um cliente. Nesse sentido, trata-se de uma relação estritamente de mercado e não política. Em última análise, o que tem o médico à frente em seu consultório é tão-somente um consumidor. O que está em jogo na sua relação com o paciente é a satisfação do assistido ao ver sua doença controlada ou curada, e nada mais além disso.

Com figuras com o mesmo padrão de comportamento de Nutels havia mais em jogo. O tratamento por si só é um fenômeno coletivo, envolve muitas pessoas, pois se percebe desde o início entre elas um laço de solidariedade, que Hochman (1998) chamou apropriadamente de "consciência de interdependência". O processo da cura envolve muito mais que o fenômeno biológico da doença, está em questão, ao mesmo tempo, a sobrevivência de um povo e a invenção de um país. Aqui o médico é, um mesmo tempo, doutor e militante político.

\section{O descompasso de uma época}

O trabalho de pesquisa de Mariza Paz (1994) foi um dos pontos de partida desse artigo. A autora se deparou, como eu, frente a essa tentadora imagem mítica que paira sobre a figura de Noel Nutels e a enfrentou de forma criativa, mas algumas vezes, ao meu ver, pouco crítica. Para cumprir o objetivo de construir historicamente a realidade social e política responsável pela emergência de figuras como a de Noel Nutels, ela recorreu a um rico e surpreendente repertório de fontes, desde jornais, documentos oficiais até depoimentos orais, a que muito devo indicações importantíssimas. Creio que discutir a interpretação 
da autora sobre a trajetória do médico é também estabelecer um debate com a historiografia sobre o desenvolvimento da saúde pública no Brasil.

A autora observou, creio que acertadamente, que as investidas da FBC pelo interior do país, embora inseridas dentro de um projeto governamental não muito claro de ocupação territorial e soberania nacional, não coincidiam inteiramente com as intenções do governo. Isto se deu, segundo ela, graças ao trabalho de atores sociais atuantes, como Noel Nutels e os irmãos Villas-Boas, que estavam envolvidos na execução das tarefas. Ao fazer isso, a autora estabelece uma distância salutar entre os interesses do Estado brasileiro, como instituição política e social, e os seus executores, que embora membros do staff governamental, não compartilhavam, muitas vezes, das mesmas aspirações.

A natureza dessa 'diferença' de interesses a autora não questiona. Mais adiante, ainda no mesmo trabalho, ela afirma que, a partir dos anos 1930, "começou a arrefecer o entusiasmo pela reforma sanitária". O que ocorre então? Ela considerou que o comportamento das instituições políticas corresponde invariavelmente ao comportamento dos agentes sociais, e vice-versa. Logo, a guinada política representada pela Revolução de 1930 deveria corresponder a uma mudança, em mesmo grau e sentido, nos padrões de comportamento dos atores sociais. Ela chega muito próximo de perceber um certo descompasso entre as esferas política e "social", por conta do surpreendente acervo documental que já comentei, mas seu esquema teórico-metodológico não permitiu fazer a distinção que julgo aqui essencial.

Devemos encarar o padrão de comportamento de Nutels, avesso às aspirações burocráticas, como uma forma fortemente inspirada em tempos anteriores. Não creio, na verdade, que ele tivesse algum princípio estritamente definido ou teoricamente formulado contra a realização dos procedimentos burocráticos em suas atividades. O problema, para citar um exemplo, era que pessoas como ele não podiam mais contar com a presença de figuras ilustres como Carlos Chagas, que na chefia do Departamento Nacional de Saúde Pública, esse uma espécie de ministério antes de sua fundação, manteve os grandes líderes da chamada reforma sanitária em postos-chave e de comando, o que favoreceu infinitamente o andamento das ações sanitárias no país. É nesse contexto que foram criados a Faculdade de Enfermagem Ana Nery, a primeira do Brasil em 1922 e, em 1925, o curso especial de higiene e saúde pública na Faculdade de Medicina do Rio de Janeiro.

No correr dos anos 1930, o quadro era outro. Aqui nos deparamos com uma crescente centralização política, somada a uma importante rotatividade e entrada de novos atores sociais nos quadros do serviço público, por conta das reformas administrativas elaboradas. ${ }^{6}$ Tudo isto, creio eu, dificulta a execução dos projetos, pois há um aumento no grau de complexidade das negociações. 
Desse modo, não creio que a partir dos anos 1930 "os ideais da reforma sanitária de Belisário Penna, Emílio Ribas e Oswaldo Cruz haviam sido abandonados" (Paz, 1994, p. 8), mas que eles tiveram que depender cada vez mais da capacidade de articulação daqueles que ainda professavam os mesmos ideais, e também não creio que fossem estes sujeitos naquela ocasião artigos em extinção.

Nutels encontrava-se, portanto, mais na esteira daqueles que estão pensando o Brasil, do que naquela cujos indivíduos estão agindo frente a uma obrigação contratual ou uma norma imposta pelos governantes de seu país. Basta atentarmos, além de tudo que já dissemos, para suas atividades como indigenista.

\section{Conclusão}

Contar a história de vida de qualquer personagem não é de fato uma tarefa muito fácil. Essa narrativa exige, por parte de quem a constrói, um tênue equilibrio entre a vida do personagem e a "sociedade" em que este vive e mantém relações de várias naturezas. Esse vínculo entre indivíduo e sociedade, há tempos tema recorrente nas ciências sociais, é muito vivo e presente nessa empreitada de pesquisa porque quero, no final das contas, demonstrar que abordar a trajetória de médicos como Noel Nutels é também tocar em inúmeras outras trajetórias, possivelmente muito similares dentro daquele contexto social. Creio que as questões que o médico enfrentou no decorrer de sua vida, suas intenções "profissionais", os desafios que encontrou e, principalmente, as soluções que forjou para a adequação de seus objetivos à dura realidade que o cercava podem muito bem ser encaradas como os conflitos de uma época.

Tentei mostrar que, ao contrário da retórica sustentada pelo próprio médico, ele era também um intelectual. Não um produtor de teses e hipóteses alheio à realidade que o contornava, mas como um "intelectual engajado", voltado para a prática de teorias e hipóteses sociológicas e antropológicas acerca da condição das raças e sociedades consideradas inferiores. A sua empreitada foi, nesse sentido, a favor do discurso da assimilação social de comunidades, fossem elas indígenas ou não, que desconheciam a presença das instituições do Estado, e nessa luta a sua ferramenta foi a saúde pública.

O material que consultei, acerca da trajetória do médico, permite apontar alguns sentidos para a interpretação dos fatos. O politizado Noel Nutels, que parece emergir nas discussões em torno do periódico Diretrizes, mantinha, a um só tempo, estreitas relações com uma certa tradição pertinente à medicina brasileira, cujos doutores há muito tinham efetiva e ampla atuação no cenário político nacional, como também ele trazia consigo uma nova característica de forte tom ideológico, muito peculiar ao seu tempo, com a influência do ideário comunista. 
O engajamento político do periódico, ${ }^{7}$ posso dizer, favorecia o sincretismo, a incorporação e a diversidade social do país, em oposição a certos princípios sustentados pelos fascismos europeus, como o racismo, a exclusão social e o extermínio. Não foi à-toa que a imagem do movimento integralista brasileiro, encarnado na figura de Plínio Salgado, foi ridicularizada em vários números da revista, como proposta e percepção equivocada da realidade e da cultura brasileiras. Na visão dos editores de Diretrizes, o nosso país possuía uma especificidade, se comparado aos países europeus. Aqui havia, na visão deles, uma cultura que respeitava a diversidade exatamente por reconhecê-la como realidade ontológica. A questão era, na visão dos jornalistas, fazer desse caldeirão de ingredientes e temperos um só prato, uma só nação.

É nesse contexto bastante amplo que o médico, de uma maneira geral, entra como um personagem importante para os destinos da nacionalidade e da nação brasileira, no sentido discutido por Castro Santos (1993, 1987, 1985, 1980) e por Lima e Hochman (1996). Quando a doença entrou, a partir da Primeira República, gradualmente em cena como elemento analítico e explicativo da realidade social do país, o debate se deslocou para as condições sanitárias de todo o território nacional. O brasileiro passou a ser visto como improdutivo não porque estava prescrito nas suas características raciais, mas porque "estava doente e abandonado pelas elites políticas. Redimir o Brasil seria saneá-lo, higienizá-lo, uma tarefa obrigatória dos governos" (Lima e Hochman, 1996, p. 23).

Creio que a guinada na percepção sobre a gente brasileira que correspondeu politicamente a um amplo movimento pela reforma da saúde pública do início do século XX encontra ainda fortes manifestações a partir dos anos 1930, e as atividades de Nutels — o que fez e como fez — são excelentes exemplos. Se não podemos dizer com toda certeza que na visão das elites políticas, o "outro" (seja um sertanejo, índio ou negro) era ainda visto como um elemento interativo importante para a constituição do quadro social, político e sanitário considerado inadequado, o mesmo não poderá ser aplicado indiscriminadamente aos médicos sanitaristas daquele período. Estes bem sabiam que o "mal do Brasil" não parecia ser fruto de uma(s) raça(s) débil(éis), mas da ausência de um Estado que organizasse e financiasse instituições sanitárias em todo o país.

Em sintonia com esses ideais historicamente instituídos, Noel Nutels pode ser visto como um dos mais eficientes porta-vozes da ideologia da agregação e inclusão social de meados do século XX. Nesse contexto, para a surpresa dos sanitaristas que viam com entusiasmo o projeto de Vargas, o processo de centralização passou a ser percebido como um desafio a toda estrutura de ação social e política conquistada e implementada pelo movimento sanitário da Primeira República (Castro Santos, 1985). Esta ruptura política, no entanto, não parece ter produzido 
uma ruptura nos debates sobre a inserção do sertão para a constituição da nacionalidade (Lima, 1999). O sertão, aqui como região não definida geográfica e politicamente, passa a ser visto, simultaneamente como espaço da barbárie (do atraso cultural) e como lugar autêntico da nacionalidade brasileira.

No contexto da virada da Revolução de 1930, segundo os trabalhos de Castro Santos (1985) e Hochman (1998), o movimento pela saúde pública teria perdido não somente uma continuidade de ação político-geográfica, mas, principalmente, seu caráter idealizador de "reconciliação e congraçamento" (Hochman, op. cit., p. 247). Nesse caso, o movimento ganharia em burocratização, o que perderia como "força ideológica" (Castro Santos, 1985, p. 207). Decerto que sim, sobretudo se entendermos o sanitarismo como uma prática levada a cabo pela conjunção de interesses sociais e políticos dados historicamente.

No entanto, se examinarmos o plano de ação daqueles médicos que eram diretamente responsáveis pela execução das políticas sociais na área de saúde pública, veremos que certas "idéias mobilizadoras" continuam a desempenhar igualmente um papelchave no contexto de incorporação das comunidades do CentroOeste brasileiro. Nesse sentido, a Revolução de 1930 não representou uma ruptura radical em relação aos ideais de congraçamento e coesão social enunciados pelo movimento sanitário, e discutidos por Castro Santos e Hochman. No pós-1930, temas como inclusão social continuam a ser alvo de debates e teses de pensadores e políticos e - o que é importante - a ser pensados nos termos e princípios da saúde pública de outros tempos. O problema parece ser, nesse caso, uma certa dificuldade de organização das instituições sociais e políticas vinculadas à execução da saúde pública a frente condições sociais transformadas.

É o nacionalismo que alavanca as discussões intelectuais, embora a questão de como se construir a nacionalidade surja como um elemento importante de cisão das elites e intelectuais do período. As tentativas de compor um projeto de assimilação de grupos e segmentos sociais, no entanto, figura como um dos pontos centrais das abordagens, seja pela via da europeização ou pela 'tupinização', algumas vezes proposta por Nutels. O fato é que, naquele contexto, a sociedade não é percebida como a soma de indivíduos, mas como uma espécie de corporação, de comunhão no espaço e no tempo. E é na manutenção dos elementos culturais considerados vitais à construção da nacionalidade que a saúde pública parece atuar, pois Noel Nutels não pretende e não salva apenas indivíduos acometidos por moléstias perigosas, mas salva, em última análise, elementos culturais.

Assim, se observarmos o indivíduo em sua plenitude, em sua dupla face, psicológica e social, teremos em mãos uma melhor compreensão não só do processo de constituição das instituições sociais que levaram 
a termo os ideais de incorporação e solidariedade social no período, mas também a trajetória social do elemento incorporado. Num mesmo instante as duas faces de uma mesma moeda.

\section{NOTAS}

${ }^{1}$ Tese de doutoramento em elaboração no Instituto de Medicina Social da UERJ, financiada pela CAPES e orientada pelo professor Luiz Antônio de Castro Santos.

2 Como construção teórico-política, a noção "espaço vital" foi cunhada no contexto dos movimentos pangermanistas, por vários escritores, alemães ou não. Adolf Hitler imprimiu, sobretudo, um sentido racista ao termo quando orientou os esforços de guerra combinando extermínio e domínio imperialista.

3 A partir das pesquisas de Edson Nunes (1997), Robert Merton (1978), Lawrence Graham (1968), Fred Riggs (1963), Reinhard Bendix (1996), Joseph Lapalombara (1963), entre outros, eu trabalho com a noção de que há um relativo descompasso estrutural entre a perspectiva patrimonialista das relações sociais e a visão burocrática, inspirada na ótica weberiana.

${ }^{4}$ Ao investigar mensagens e decretos presidenciais durante a gestão Getúlio Vargas, pude perceber uma significativa mudança nos assuntos técnico-administrativos operados pelo executivo federal. Os dados revelam que quase toda reforma teve como foco profundas alteraçoes nos quadros de pessoal do Estado brasileiro, rumo a um sistema de carreira de divisão do trabalho mais complexo, se comparado com o que até então estava instituído. Sobre o assunto, ver também Wahrlich (1983) e Graham (1968).

5 Fernando Uricoechea (1978) coloca o período imperial como ponto de partida de uma burocracia no país, em razão da atuação das próprias agências burocráticas centrais que pressionavam pela progressiva racionalização na administração pública; em segundo lugar, pelo forte impacto racionalizador na economia e na sociedade produzido pela indústria do café e; por último, em virtude da emblemática guerra do Paraguai (1864-70), que incitou a administração federal a uma racionalização compulsória dos recursos e finanças nacionais, diante do conflito sem precedentes e de grandes proporções. Creio que apesar de todos os esforços rumo a uma concepção de administração pública mais técnica, racionalizada e burocrática, frente à visão personalista, paternalista e patrimonialista da época, devemos localizar no período somente a gênese do processo de burocratização, pois ele não se institui abruptamente. Não é no século XIX que as normas burocráticas procuraram indicar, de maneira muito peculiar, as regras do jogo, mas, como quero fazer crer, no correr dos anos que se seguem à Revolução de 1930, quando uma seqüência de reformas político-administrativas, dentro de um quadro geral de transformações sociais, dá nova organização ao aparelho do Estado. Assim, creio que sustentar a existência de uma burocracia, aos moldes weberianos, durante o século XIX seja talvez carregar nas cores uma realidade burocrática ainda bastante tímida e discreta.

${ }^{6}$ Conforme demonstrou Beatriz Wahrlich (1983), as primeiras idéias acerca da necessidade de uma reforma administrativa que atualizasse o funcionamento do Estado brasileiro aparece já na plataforma da Aliança Liberal, sob o título "o problema do funcionalismo". A tônica da Aliança, como se poderia confirmar posteriormente, estava na necessidade de colocar o presidente da República no centro das decisões governamentais, como o principal baluarte na coordenação das políticas públicas em todo o território nacional. A partir desse pressuposto elementar, lança-se foco sobre departamentos, instituições e comissões que arregimentavam o aparelho do Estado. Agora, segundo os porta-vozes dos novos tempos, devia-se criar toda uma estrutura político-administrativa que desse voz às intenções levantadas como bandeira pela Aliança que viabilizou o golpe de Estado, sobretudo, a necessidade de centralização política. Pelo decreto 19.398, de 11 de novembro de 1930, ainda sob o calor do ímpeto revolucionário de agosto, instituiu-se que somente ao Presidente da República cabia as nomeações e demissões de funcionários do Estado. Nesse mesmo mês ficou determinado que o governo provisório passaria por importantes transformações ministeriais. É nesse quadro que foi criado o Ministério da Educação e Saúde Pública (decreto 19.402, de 14 de novembro de 1930). Essa pasta foi organizada a partir de repartições do Ministério da Justiça e Negócios Interiores (onde se concentravam muitas decisões acerca do tema saúde), do Ministério da Viação e Obras Públicas e do Ministério da Agricultura, Indústria e Comércio. Além disso, todo o terremoto político provocado, principalmente pelos paulistas, que culminou na necessidade de uma carta magna para o país em 1934, deixou marcas importantes no processo de burocratização estatal. Uma das mais importantes medidas, e que nos interessa bem de perto, foi a lei 284 , de 28 de outubro de 1936, que aprovou o primeiro plano de cargos e institucionalizou o sistema de mérito, previsto pela constituição liberal de 1934. O Conselho Federal do Serviço Público, criado pela lei 284, funcionou por período curto, até meados de 1938, quando foi substituído pelo Departamento de Administração do Serviço Público (DASP), que absorveu muitas de suas funções. O conselho já tinha executado muitas das atribuições que marcaram a trajetória do DASP, principalmente a elaboração de concursos públicos para ingresso no quadro do funcionalismo público.

${ }^{7}$ Consultei o material publicado de abril de 1938 até o final de 1943. 


\section{REFERÊNCIAS BIBLIOGRÁFICAS}

Bendix, Reinhard

1996

Castro Santos, L. A. de 1993

Castro Santos, L. A. de 1987

Castro Santos, L. A. de 1985

Castro Santos, L. A. de 1980

Fausto, Boris 2000

Fausto, Boris. jul.-1990

Fausto, Boris 1968

Graham, Lawrence S. 1968

Hobsbawm, Eric 1995

Hochman, Gilberto 1998

Houaiss, Antônio (org.) 1974

Lapalombara, Joseph 1963

Lapalombara, Joseph 1963

Lessa, Orígenes 1978

Lima, Nísia Trindade 1999

Lima, Nísia T. e Hochman, Gilberto 1996

Menezes, Maria Lúcia Pires 2000

Merton, Robert K. 1978

Merton, Robert K. 1968
'Autoridade administrativa no Estado-nação'.

Em Construção nacional e cidadania. Estudos de nossa ordem social em mudança. Trad. Mary Amazonas Leite de Barros. São Paulo, Editora da Universidade de São Paulo, pp. 139-78. Clássicos, 5.

'A reforma sanitária pelo alto: o pioneirismo paulista no início do século XX'. Dados - Revista de Ciências Sociais, Rio de Janeiro, vol. 36, nº 3, pp. 361-92.

Power, ideology and public health in Brazil (1889-1930).

Tese de doutoramento, Cambridge, Harvard University

'O pensamento sanitarista na República Velha: uma ideologia de construção da nacionalidade. Dados - Revista de Ciências Sociais, Rio de Janeiro, vol. $28, \mathrm{n}^{\mathrm{O}} 2$, pp. 193-210.

'Estado e saúde pública no Brasil (1889-1930)'.

Dados - Revista de Ciências Sociais, Rio de Janeiro, vol. 23, no 2, pp. 237-50.

História do Brasil.

8ª ed., São Paulo, Fundação para o Desenvolvimento da Educação.

'Estado e burguesia agroexportadora na Primeira República: uma revisão historiográfica'. Novos Estudos CEBRAP, São Paulo, no 27, pp. 120-26.

'A Revolução de 1930'. Em Fernando Henrique Cardoso, Brasil em perspectiva. São Paulo, Difusão Européia do Livro, pp. 255-84. Coleção Corpo e Alma do Brasil.

Civil service reform in Brazil: principles versus practice.

Texas, University of Texas Press.

A era das extremos. O breve século XX (1914-1991).

Trad. Marcos Santarrita. São Paulo, Companhia das Letras.

A era do saneamento: as bases da política de saúde pública no Brasil. São Paulo, Hucitec/ANPOCS.

Noel Nutels: memórias e depoimentos.

Rio de Janeiro, José Olympio.

'Burocracia y desarrollo politico. Consideraciones generales'. Em J. Lapalombara (org.), Burocracia y desarollo político. Buenos Aires, Editorial Aidos, pp. 15-39.

'Burocracia y desarrollo político. Notas, interrogantes y dilemas'.

Em J. Lapalombara (org.), Burocracia y desarollo político.

Buenos Aires, Editorial Aidos, pp. 40-61.

O índio cor de rosa: evocação de Noel Nutels.

Rio de Janeiro, Codecri. Coleção edições do Pasquim, vol. 22.

Um sertão chamado Brasil: intelectuais e representação geográfica da identidade nacional. Rio de Janeiro, Revan/IUPERJ.

'Condenado pela raça, absolvido pela medicina: o Brasil descoberto pelo Movimento Sanitarista da Primeira República'. Em Marcos Chor Maio e Ricardo Ventura Santos (orgs.), Raça, ciência e sociedade.

Rio de Janeiro, Fiocruz/CCBB, pp. 23-40.

Parque Nacional do Xingu: a construção de um território estatal. São Paulo, Editora da Unicamp/Imprensa Oficial.

'Estrutura burocrática e personalidade'.

Em E. Campos (org.), Sociologia da burocracia.

Rio de Janeiro, Zahar, pp. 107-24.

Sociologia: teoria e estrutura.

Trad. Miguel Maillet. São Paulo, Mestre Jou. 
Nunes, Edson

1997

Paz, Mariza Campos da

1994

Riggs, Fred W.

1963

Uricoechea, Fernando 1978

Wahrlich, Beatriz de Souza

1983

Weber, Max

1971

Weber, Max

1944

Weiner, Samuel

1989

A gramática política do Brasil: clientelismo e insulamento burocrático. Rio de Janeiro/Brasília, Jorge Zahar, Escola Nacional de Administração Pública.

Noel Nutels: a política indigenista e a assistência à saúde no Brasil central (1943-1973). Dissertação de mestrado, Rio de Janeiro, UERJ/IMS.

'Los burocratas y el desarollo político: una concepcion paradojica'.

Em J. Lapalombara (org.), Burocracia y desarollo político.

Buenos Aires, Editorial Aidos, pp. 113-56.

O minotauro imperial: a burocratização do estado patrimonial brasileiro no século XIX’. Em Fernando Henrique Cardoso, Brasil em perspectiva. Rio de Janeiro/São Paulo, DIFEL. Coleção Corpo e Alma do Brasil.

Reforma administrativa na era Vargas.

Rio de Janeiro, Editora da Fundação Getúlio Vargas.

Ensaios de sociologia.

Trad. Waltensir Dutra. Rio de Janeiro, Zahar.

Economia y sociedad.

Trad. Johannes Winckelmann. México, Fundo de Cultura Econômica.

Minha razão de viver: memórias de um repórter.

Rio de Janeiro, Record.

Recebido para publicação em dezembro de 2002.

Aprovado para publicação em março de 2003. 